\title{
Analysis of Mycobacterium avium Complex Serovars Isolated from AIDS Patients from Southeast Brazil
}

\author{
Maria Helena Féres Saad/ ${ }^{+}$, Veronique Vincent*, David J Dawson**, \\ Moisés Palaci***, Lucilaine Ferrazoli***, Leila de S Fonseca****
}

\begin{abstract}
Laboratório de Hanseníase, Instituto Oswaldo Cruz, Av. Brasil 4365, 21045-900 Rio de Janeiro, RJ, Brasil *Institut Pasteur, Centre Nationale de Reference pour les Mycobactéries, Paris, France **Queensland Health, Laboratory of Microbiology and Pathology, Brisbane, Australia ***Instituto Adolfo Lutz, Laboratório de Referência para Micobactérias, São Paulo, Brasil ****Instituto de Microbiologia, Universidade Federal do Rio de Janeiro, RJ, Brasil
\end{abstract}

The purpose of this study was to assess the distribution of Mycobacterium avium serovars isolated from AIDS patients in São Paulo and Rio de Janeiro. Ninety single site or multiple site isolates from 75 patients were examined. The most frequent serovars found were $8(39.2 \%), 4(21.4 \%)$ and 1 (10.7\%). The frequency of mixed infections with serovar 8 or 4 was 37.8\%. Among the 90 strains examined, M. intracellulare serovars (7 strains) and $\mathrm{M}$. scrofulaceum (4 strains) were found in 11 isolates (12\%) indicating that M. avium (88\%) was the major opportunistic species in the M. avium complex isolates in Brazilian AIDS patients.

Key words: seroagglutination - serovars - mycoside C - glicopeptidolipids - Mycobacterium avium

Non tuberculous mycobacteria belonging to the Mycobacterium avium complex (MAC) have been increasingly recognized as an important group of organisms causing severe opportunistic infection in patients with acquired immunodeficiency syndrome (AIDS) in the United States (Kiehn et al. 1985, Young et al. 1986, Horsburgh \& Selik 1989, Nassos et al. 1991, Havlik et al. 1992), Europe (Yates et al. 1986, Wickman 1986, Peters et al. 1989, Grange et al. 1990) and Australia (Dawson 1990). In Brazil an increase in the frequency of M. avium complex infections has also been found associated with AIDS patients (Barreto et al. 1993, Landgraf et al. 1994). Recognition of the importance of MAC infection in AIDS has stimulated epidemiological studies concerning it. Most of the studies have been done in the USA, some in Europe; however none in Brazil.

MAC may be typed by using a seroagglutination assay described by Schaefer (1965). Currently the serovars 1 through 6,8 through 11 and 21 are recognized as $M$. avium, 7, 12 through 28 as $M$. intracellulare while serotypes 41 through 43 are designated $M$. scrofulaceum. Serotyping is based on the presence of specific oligosaccharide

\footnotetext{
This work was supported by CNPq and FINEP (Brasil). ${ }^{+}$Corresponding author. Fax: +55-21-270.9997. E- mail: Saad@gene.dbbm.fiocruz.br Received 4 December 1996 Accepted 22 April 1997
}

haptens (Brennan \& Goren 1979, Brennan et al. 1981, McNeil et al. 1987) that form the sugar moiety of glycopeptidolipids (GPL), located on the cell surface of smooth-colony-forming strains. Rough colony variants are not amenable for serotyping because they agglutinate spontaneously. However, their GPL can be extracted and analyzed by thin layer chromatography (TLC) procedures (Brennan \& Goren 1979).

Significant geographic differences have been reported in the major serotypes infecting AIDS patients (Kiehn et al. 1985, Horsburgh et al 1986). Furthermore, these serotypes infecting AIDS patients also differ from those predominantly infecting non-AIDS patients (Yakrus \& Good 1990, Tsang et al. 1992).

In order to examine the predominant serotypes infecting patients, we analyzed MAC strains isolated from AIDS patients combining both agglutination according to Schaefer (1980) and the nature of the GPLs identified by TLC. The MAC strains were isolated from São Paulo and Rio de Janeiro, where the rate of AIDS infection is the highest in Brazil (Ministério da Saúde 1996).

\section{MATERIALS AND METHODS}

Selected isolates - A total of 90 strains, isolated from clinical specimens from 75 AIDS patients, between 1991 and 1994, in the cities of São Paulo and Rio de Janeiro were studied. The strains were from the Instituto Adolfo Lutz in São Paulo (SP) $(n=67)$, and from three different microbiology laboratories in Rio de Janeiro: Hospital 
Evandro Chagas (FIOCRUZ) $(\mathrm{n}=7)$, Hospital Universitário Clementino Fraga Filho (UFRJ) (n = 4) and Centro de Referência Professor Hélio Fraga (Health Ministry) $(n=12)$, most of them being from Rio de Janeiro (RJ). Forty-seven strains were isolated from sterile sites (41 blood, 2 lymph nodes, 1 cerebrospinal fluid and 3 bone marrow), and 40 from non-sterile sites (29 sputum, 4 bronchialveolar lavage, 3 faeces, 3 urine and 1 ear), while three were from unknown sites. The isolates were identified by conventional biochemical tests. Twelve patients had multiples isolates $(\mathrm{n}=$ 27) from different body sites or from the same body site at different times. Specimen source and patient information were obtained from microbiology laboratory records.

Serotyping - The smooth colonies were serotyped by direct agglutination following modified Schaefer's procedure (Schaefer 1980), using rabbit antisera raised against each member of the MAC (serovars 1-28) and M. scrofulaceum (serovars 41-43). The strain suspensions for serotyping were prepared as follows: the organisms were cultured on Lowenstein-Jensen medium incubated at $37^{\circ} \mathrm{C}$ for two weeks, or until heavy growth was obtained. The growth was harvested by scraping gently with loop and flooding into 1 $\mathrm{ml}$ of $0.5 \%$ phenol phosphate buffered saline (PPBS). The suspensions were killed by heating at $80^{\circ} \mathrm{C}$ for $1 \mathrm{hr}$. After shaking, the suspensions were let stand for $1 \mathrm{hr}$ to allow clumps to sediment and the heavily turbid supernatant was then used for serotyping. The serotyping procedure was performed in the Microbiology and Pathology Laboratory, Queensland Health, Brisbane, Australia.

Thin layer chromatography - The extraction and preparation of the alkali-stable glycopeptidolipid antigen from fresh growth were performed as described previously (Tsang at al. 1983), with minor modifications: the organisms were cultured as described above. The growth was heavily harvested by scraping gently with loop and mixed into $1.5 \mathrm{ml}$ of chloroform-methanol 2:1, v/v (C:M) and the suspension was then heated overnight at $56^{\circ} \mathrm{C}$. One hundred $\mu \mathrm{l}$ of the clear crude lipid extracts were then mixed with the same volume of methanol containing $0.2 \mathrm{M} \mathrm{NaOH}$. The reaction was incubated at $37^{\circ} \mathrm{C}$ for $20 \mathrm{~min}$, to saponify other complex lipids, then the reaction was acidified with $2.5 \mu \mathrm{l}$ of acetic acid and dried. To the extract 500 $\mu \mathrm{l}$ of C:M and $100 \mu \mathrm{l}$ of water were added. After 10 min of centrifugation, the aqueous phase was discarded and the extract was dried. The dried extract was solubilized in $30 \mu \mathrm{l}$ of $\mathrm{C}: \mathrm{M}$, applied to silica gel TLC plates (HP-K, Merck, Germany) and then chromatographed using C:M: $\mathrm{H}_{2} 0$ (65:25:4) and C:M (80:20). The C-mycoside GPL antigens were revealed using the $0.2 \%$ solution of anthron in sulfuric acid spray reagent. Reference cultures of $M$. avium were used as the internal standard for each of the M. avium complex mycosides.

\section{RESULTS}

This is the first time that Brazilian MAC clinical isolates have been examined with respect to serotyping and mycoside content. Both procedures were applied to 39 strains; 8 (20.5\%) were nontypeble (or autoagglutinated) by seroagglutination, but all strains could be typed by their characteristic GPL mycosides. Among 31 strains that were typed by both methods, there were $3(9.67 \%)$ in disagreement. Although, there was good agreement between the two methods (90.4\%) a large proportion of the strains were untypeble or autoagglutinated using seroagglutination, despite the presence of characteristic GPLs in all strains tested. Consequently, only the mycoside content was used in the following analysis of the data.

Seventy-five patients yielded 90 isolates; 56 (62.2\%) showed a single serovar (group I) while in $34(37.8 \%)$ more than one serovar was identified (group II). The serovars identified from the first group of isolates are depicted in Table I. The predominant serovars were 8,4 and $1(39.2 \%$, $21.4 \%$ and $10.7 \%$ of the isolates, respectively). No significant difference was found between isolates from sterile and non-sterile sites $\left(\mathrm{X}^{2}=1.12\right.$; $\mathrm{p}=0.29$ ). From group II distinct serovars were seen, the mixed serovars were identified in 19 isolates

\section{TABLE I}

Results of serotyping of Mycobacterium avium complex strains isolated from AIDS patients, which showed a single serovar

\begin{tabular}{|c|c|c|c|c|}
\hline \multirow[b]{2}{*}{ Serovars } & \multicolumn{4}{|c|}{$\begin{array}{l}\text { Number of isolates with single serovar } \\
\text { by site of isolation }\end{array}$} \\
\hline & $\begin{array}{l}\text { Sterile }^{a} \\
\quad(\%)\end{array}$ & $\begin{array}{c}\text { Non-sterile }{ }^{b} \\
(\%)\end{array}$ & $\begin{array}{l}\text { Unknown } \\
(\%)\end{array}$ & $\begin{array}{l}\text { Total } \\
(\%)\end{array}$ \\
\hline 1 & $2(7.1)$ & 4 (16.6) & & $6(10.7)$ \\
\hline 2 & $2(7.1)$ & 1 ( 4. & & $3(5.4)$ \\
\hline 3 & 1 (3.6) & $2(8.3$ & & $3(5.4)$ \\
\hline 4 & $7(25.0)$ & $5(20.8)$ & & $12(21.4)$ \\
\hline 5 & 1 (3.6) & $1(4.2)$ & & $2(3.8)$ \\
\hline 6 & 1 (3.6) & & & 1 (1.8) \\
\hline 8 & $12(42.8)$ & $7(29.2)$ & $3(75.0)$ & $22(39.2)$ \\
\hline 9 & & $3(12.5)$ & $1(25.0)$ & $4(7.1)$ \\
\hline 10 & 1 (3.6) & & & 1 (1.7) \\
\hline $12^{c}$ & & 1 (4.2) & & 1 (1.7) \\
\hline 21 & $1(3.6)$ & & & 1 (1.8) \\
\hline Total & $28(50.0)$ & $24(42.8)$ & $4(7.2)$ & $56(100.0$ \\
\hline
\end{tabular}

$a$ : blood, bone marrow, lymphnode, liquor; $b$ : sputum, bronchialveolar lavage, stool, skin, ear, urine; $c$ : $\mathrm{Myco-}$ bacterium intracellulare. 
from a single site (55.9\%) (Table II) and in 15 $(44.1 \%)$ distinct serovars were isolated from different sites or from the same site but at different times (Table III). As shown in Table II, the most common serovars in mixed infections from single sites were 8 and 4 (34.2\% and $21.1 \%$, respectively). Among the 12 patients with multiple isolates, 27 strains were typed (Table III). Also, serovars 8 and 4 were more frequent $(10 / 27,37 \%$ and $7 / 27,25.9 \%$, respectively).

Considering all isolates, they were arranged to the species $M$. avium (88\%), M. intracellulare (7.8\%), and M. scrofulaceum (4.2\%). Consequently $M$. avium was the main specie of the MAC infecting the patients.

\section{TABLE II}

Frequency of Mycobacterium avium complex serovars identified by mycosid content in 19 single isolates which showed mixed serovars

\begin{tabular}{cr}
\hline Serovars & Number $(\%)^{c}$ \\
\hline 1 & $2(5.3)$ \\
2 & $4(10.5)$ \\
4 & $8(21.1)$ \\
5 & $1(2.6)$ \\
$7^{a}$ & $1(2.6)$ \\
8 & $13(34.2)$ \\
9 & $1(2.6)$ \\
$16^{a}$ & $1(2.6)$ \\
$17^{a}$ & $3(7.9)$ \\
$23^{a}$ & $3(7.9)$ \\
$42^{b}$ & $1(2.7)$ \\
\hline
\end{tabular}

a: Mycobacterium intracellulare; $b$ : M. scrofulaceum; $c$ : number of strains in which the serovar was identified.

\section{DISCUSSION}

The purpose of this study was to assess the distribution of $M$. avium serovars from patients with AIDS in Brazilian centers that show the highest rate of AIDS infection. Since MAC infection is the second most important mycobacteriosis associated with AIDS, this study was performed with MAC isolated from AIDS patients from São Paulo and Rio de Janeiro. The serovars were established accordingly to the GPL (mycoside C) content of the isolates.

A majority of the isolates ( $88 \%$ ) were assigned to the $M$. avium serovars. When the serovars were ranked according to the isolated strains the results were: serovar $8,39.2 \%$; serovar $4,21.4 \%$; serovar 1, 10.7\%; mixed serovars 8 and 4,37.8\%. In this report, the predominant serovars in our study were similar to those in the USA, Canada and Australia
TABLE III

Serovars of 27 Mycobacterium avium strais from 12 patients with multiple isolates

\begin{tabular}{|c|c|c|c|}
\hline $\begin{array}{l}\text { Patient } \\
\text { number }\end{array}$ & $\begin{array}{c}\text { Site of } \\
\text { isolation }\end{array}$ & IsoDate $^{a}$ & Serotypes \\
\hline 15 & $\begin{array}{l}\text { Blood } \\
\text { Blood }\end{array}$ & $\begin{array}{l}02 / 09 / 93 \\
02 / 27 / 93\end{array}$ & $\begin{array}{l}11 / 5 \\
8 / 23^{b}\end{array}$ \\
\hline 19 & $\begin{array}{l}\text { Blood } \\
\text { Blood }\end{array}$ & $\begin{array}{l}02 / 09 / 93 \\
02 / 19 / 93\end{array}$ & $\begin{array}{l}8 / 42^{c} \\
8\end{array}$ \\
\hline 22 & $\begin{array}{l}\text { Blood } \\
\text { Sputum }\end{array}$ & $\begin{array}{l}03 / 22 / 93 \\
06 / 04 / 93\end{array}$ & $\begin{array}{l}8 / 9 \\
8 / 9\end{array}$ \\
\hline 25 & $\begin{array}{l}\text { Sputum } \\
\text { Blood }\end{array}$ & $\begin{array}{l}07 / 27 / 93 \\
07 / 30 / 93\end{array}$ & $\begin{array}{l}1 / 12^{b} \\
2 / 1\end{array}$ \\
\hline 28 & $\begin{array}{l}\text { Sputum } \\
\text { Blood } \\
\text { Liquor }\end{array}$ & $\begin{array}{l}04 / 16 / 93 \\
08 / 17 / 93 \\
10 / 17 / 93\end{array}$ & $\begin{array}{l}1 \\
1 / 6 \\
1\end{array}$ \\
\hline 34 & $\begin{array}{l}\text { Sputum } \\
\text { Marrow } \\
\text { Blood }\end{array}$ & $\begin{array}{l}11 / 18 / 92 \\
12 / 21 / 92 \\
12 / 21 / 92\end{array}$ & $\begin{array}{l}4 \\
2 / 1 \\
4\end{array}$ \\
\hline 35 & $\begin{array}{l}\text { Blood } \\
\text { Faeces }\end{array}$ & $\begin{array}{l}09 / 04 / 92 \\
09 / 04 / 92\end{array}$ & $\begin{array}{l}8 \\
4\end{array}$ \\
\hline 39 & $\begin{array}{l}\text { Ear } \\
\text { Urine }\end{array}$ & $\begin{array}{c}02 / 13 / 92 \\
1993\end{array}$ & $\begin{array}{l}8 \\
8\end{array}$ \\
\hline 45 & $\begin{array}{l}\text { Lynphonode } \\
\text { Blood }\end{array}$ & $\begin{array}{l}07 / 25 / 91 \\
07 / 26 / 91\end{array}$ & $\begin{array}{l}6 / 23^{b} \\
21 / 2\end{array}$ \\
\hline 48 & $\begin{array}{l}\text { Blood } \\
\text { Sputum }\end{array}$ & $\begin{array}{l}07 / 26 / 94 \\
11 / 11 / 94\end{array}$ & $\begin{array}{l}4 / 42^{c} \\
4 / 42^{c}\end{array}$ \\
\hline 51 & $\begin{array}{l}\text { Blood } \\
\text { Sputum } \\
\text { Faeces }\end{array}$ & $\begin{array}{l}03 / 08 / 94 \\
05 / 16 / 94 \\
06 / 13 / 94\end{array}$ & $\begin{array}{l}4 / 8 \\
4 \\
4 / 8\end{array}$ \\
\hline 94 & $\begin{array}{l}\text { Sputum } \\
\text { Blood }\end{array}$ & $\begin{array}{l}07 / 08 / 93 \\
09 / 20 / 93\end{array}$ & $\begin{array}{l}5 \\
5\end{array}$ \\
\hline
\end{tabular}

$a$ : clinical specimen isolation data; $b: M$. intracellulare; c: M. scrofulaceum.

(Horn et al. 1989, Yakrus \& Good 1990, Dawson 1990, Tsang et al. 1992) and distinct from those in Germany, Sweden and the United Kingdom (Ruf et al. 1989, Hoffner et al. 1990, De Smet et al. 1996). Geographic differences may be related to a combination of factors such as: prevalence of determinate serovars in the environment, differences in bacterial virulence factors and host immunoresponse status, since AIDS patients are particularly susceptible to determinate serovars of MAC. Like others (Yakrus \& Good 1990, Tsang et al. 1992) we did not find significant differences between the isolates from sterile and non-sterile sites.

The frequency of mixed serovars in our patients was higher than reported by others. For instance, in a large-scale study Tsang et al. (1992) observed $6 \%$ mixed serovars while in this study we observed 
37.8\%. In another study, Dawson (1990) found multiple serovars among isolates from multiple sites in 38\% of 45 patients examined, and Hoffner et al. (1990) found $24.9 \%$ of multiple serovars from distinct body sites of isolation. Whether these difference are attributed to the size of the populations sampled (6,264 cultures in the Tsang et al. 1992 study as compared to only 90 isolates in the present study) or to environmental factors requires further investigations.

The occurrence of mixed infections raises important questions regarding the management of $M$. avium infections, particularly in the event that serovars from distinct sites have distinct drug resistance patterns (von Reyn et al. 1995). Mixed infections (polyclonal infections) have also been demonstrated using RFLP assays (Von Reyn et al. 1996). The frequency of mixed infections reported varied widely (Arbeit \& Slutsky 1993, Slutsky \& Arbeit 1994) leading to the suggestion that most studies indeed underestimate the rate of polyclonal infection in AIDS patients. The mixed serovar infection finding is not easy to evaluate. Our first thought was that this could be a consequence of immunecompromised patients exposed to multiple environmental sources of MAC, since this organism is ubiquitous in nature. This is corroborated by von Reyn et al. (1996), which suggests that mixed infection may represent a synergic infection between two different MAC.

The importance of epidemiological and clinical implications of mixed (polyclonal) infections in AIDS patients indicate that further investigation is necessary. Consequently, we are proceeding to a study of Brazilian isolates by DNA fingerprint using the IS1245 insertion sequence in order to establish the genetic identity of the strains.

\section{ACKNOWLEDGEMENTS}

To Dr Angela W Barreto and Dr Fátima Martins from Centro de Referência Prof. Hélio Fraga, and Dr Fátima Fandinho and Cristina L Almeida from Fundação Oswaldo Cruz, for supplying several of the clinical Mycobacterium avium complex isolates for analysis. $\mathrm{To} \mathrm{Dr}$ Hugo David from Instituto de Higiene e Medicina, Universidade de Lisboa, Portugal for reviewing the manuscript. To Anne Varnerot from Institute Pasteur for technical advice.

\section{REFERENCES}

Arbeit RD, Slutsky A 1993. Genetic diversity of $M$. avium strains causing monoclonal and polyclonal bacteremia in patients with AIDS. J Infect Dis 167: 1384-1390.

Barreto JA, Palaci M, Ferrazoli L, Martins MC, Suleiman J, Lorenço OC, Ferreira Jr L, Riley LW, Johnson WD, Ayrosa Galvão PA 1993. Isolation of M. avium complex from bone marrow aspirates of AIDS pa- tients in Brazil. J Infect Dis 168: 777-779.

Brenann PJ, Goren MB 1979. Strutural studies on the type-specific antigens and lipids of $M$. avium- $M$. intracellulare-M. scrofulaceum complex. J Biol Chem 254: 4205-4211.

Brenann PJ, Aspinall GO, Nam Shin JE 1981. Structure of the specific oligosaccharides from the peptidoglicolipid antigens of serovars in the $M$. avium-M. intracellulare-M. scrofulaceum complex. J Biol Chem 256: 6817-6822.

Brennan PJ, Heifets M, Ullom BP 1982. TLC of lipid antigens as a means of identifying nontuberculous mycobacteria. J Clin Microbiol 15: 447-455.

Dawson DJ 1990. Infection with M. avium complex in Australian AIDS patients with AIDS. Med J Aust 153: 466-468.

De Smet KLA, Hellyer TJ, Khan AW, Btown IN, Yvanyi J 1996. Genetic and serovar typing of clinical isolates of M. avium-intracellulare complex. Tubercle Lung Dis 77: 71-76.

Grange JM, Yates MD, Boughton E 1990. The avium tubercle bacillus and its relatives. J Appl Bacteriol 68: 411-431.

Havlik JA, Horsburgh Jr CR, Metchock B, Williams PP, Fann SA, Thompson III SE 1992. Disseminated $M$. avium complex infection: clinical identification and epidemiologic trends. I Infect Dis: 165: 577-580.

Hoffner SE, Källenius G, Petrini B, Brennan PJ, Tsang AY 1990. Serovars of M. avium isolates from patients in Sweden. J Clin Microbiol 28: 1105-1107.

Horsburgh CR, Selik R 1989. The epidemiology of disseminated nontuberculous mycobacterial infection in the acquired immunodeficiency syndrome (AIDS). Am Rev Resp Dis 13: 94-97.

Horn R, Laszlo DL, Robson HL 1989. Recovery M. avium- $M$. intracellulare from blood specimens by using the routine BACTEC isolates from patients with or without acquired immunodeficiency syndrome. Antimicrob Agents Chemother 30: 955-957.

Kiehn TE, Edwards FF, Brennan PJ, Tsang AY, Maio M, Gold JW, Whimbey E, Wong B, McClatchy K, Armstrong D 1985. Infections caused by M. avium complex in immunecompromised patients: diagnosis by blood culture and fecal examination, antimicrobial susceptibility tests, and morphological and seroagglutination characteristics. J Clin Microbiol 21: $168-173$.

Landgraf IM, Palaci M, Vieira MFP, Ueki SYM, Martins MC, Sato DN, Ferrazoli L, Telles MAS, Gorla MC, Vaz TMI, Lorenço R, Marques LRM 1994. Bacterial agents isolated from cerebrospinal fluid of patients with AIDS and neurological complications. Rev Inst Med Trop São Paulo 36: 491-496.

McNeil MA, Tsang AY, Brenann PJ 1987. Struture and antigenicity of the specific oligosaccharide hapten from the glicopeptidolipid antigen of $M$. avium serotype 4, the dominant mycobacterium isolated from patients with AIDS. J Biol Chem 262: 2630-2635.

Ministério da Saúde 1996. Boletim Epidemiológico de AIDS 9: 14.

Nassos PS, Yajko DM, Sanders CA, Hadley WK 1991. Prevalence of M. avium complex in respiratory speci- 
mens from AIDS and non-AIDS patients in San Francisco Hospital. Am Rev Resp Dis 143: 66-68.

Peters M, Schürmann D, Mayr AC, Hetzer R, Pohle HD, Ruf B 1989. Immunosupression and mycobacteria other than M. tuberculosis: results from patients with and without HIV infection. Epidemiol Infect 103: 293-300.

Ruf B, Peters M, Schröder HJ, Pohle HD 1989. Mycobacterium avium-intracellulare serovars in Germany AIDS patients. The Lancet ii: 1101.

Schaefer WB 1965. Serologic identification and classification of the atypical mycobacteria by their agglutination. Am Rev Resp Dis 92 (Suppl.): 85-93.

Schaefer WB 1980. Serological identification of atypical mycobacteria. Methods Microbiol 13: 323-344.

Slutsky AM, Arbeit RD 1994. Polyclonal infection due M. avium complex in patients with AIDS detected by PFGE of sequencial clinical isolates. J Clin Microbiol 32: 1773-1778.

Tsang AY, Denner JC, Brennan PJ, McClatchy JK 1992. Clinical and epidemiological importance of typing of $M$. avium complex isolates. J Clin Microbiol 30: 479-484.

Tsang AY, Drupa I, Goldberg M, McClatchy K, Brennan PJ 1983. Use of serology and thin-layer chromatography for the assambly of an authenticated collection of serovars within the $M$. avium-M.
intracellulare-M. scrofulaceum complex. Int J System Bacteriol 333: 285-292.

von Reyn CF, Jacobs NJ, Arbeit RD, Maslow DJ, Niemczyk S 1995. Polyclonal M. avium complex in patients with AIDS: variations in antimicrobiol susceptibilities of different strains of $M$. avium isolated from the same patient. J Clin Microbiol 33: 10081010.

von Reyn CF, Pestel M, Arbeit RD 1996. Clinical and epidemiologic implications of polyclonal infection due to M. avium complex. Res Microbiol 147: 7121.

Yakrus MA, Good RC 1990. Geographic distribution, frequency and specimen source of $M$. avium complex serotypes isolates from patients with AIDS. $J$ Clin Microbiol 28: 926-929.

Yates MD, Grange JM, Collins CH 1986. The nature of mycobacterial disease in south east England, 197784. J Epidemiol Communty Health 40: 295-300.

Young LS, Inderlied CB, Berlin OG, Gottlieb MS 1986. Mycobacterial infections in AIDS patiients, with emphasis on the M. avium complex. Rev Infect Dis 8: 1024-1033.

Wickman K 1986. Clinical significance of nontuberculous mycobacteria. A bacteriological survey of Swedish strains isolated between 1973 and 1981. Scandin J Inf Dis 18: 337-345. 
M. avium Complex Serovars in Southeast Brasil - MHF Saad et al. 